\title{
Are our Special Education Students Ready for Work? An investigation of the teaching of job- related social skills in Northern Taiwan
}

\author{
Yin-An Chu' and Liang-Cheng Zhang ${ }^{*}$ \\ a Department of Education, National Taiwan Normal University, Taipei City, \\ Taiwan, ROC; bDepartment of Accounting, Finance and Economics, Griffith \\ Business School, Griffith University, Nathan, Queensland, Australia
}

This study is concerned with the current job preparation programmes for special education students in Taiwan. Two hundred and three randomly selected special education teachers in Northern Taiwan responded to a questionnaire about job-related social skills. The relationship between teachers' demographic characteristics and their teaching of job-related social skills was examined. In general, teachers' pedagogical practices were found to focus more on the basic job-related social skills (such as proper attire, hygiene, punctuality and attendance) than on the advanced job-related social skills (such as cooperation and emotion management). Interestingly, teachers with a special education degree tended to nurture both dimensions of job-related social skills. Additionally, teacher experience was found to be a key contributor to the teaching of job-related social skills, with less experienced teachers more likely to downplay the teaching of such skills.

Keywords: career employment, general vocational teacher, job loss, job-related social skills, special education student, survey, Taiwan, teaching.

\section{Introduction}

Many high school graduates with disabilities are not well prepared for the workplace. These young people are challenged by poor work ethic, lifestyle adjustment issues, interpersonal relation problems and poor communication skills (Ofoegbu \& Azarmsa, 2010; Wehman, Fong, Ditchman \& Hyun-Ju, 2014). For example, vocational high school graduates with mild intellectual disabilities were found to exhibit poor work ethics and little interest in work, these

\footnotetext{
${ }^{*}$ Corresponding author. Email: liang-cheng.zhang@griffithuni.edu.au
} 
being the two main reasons for the loss of their jobs (Chen \& Lin, 2000). In another study, Chen and Wang (2007) found that these graduates had poor job-related skills, inadequate attitudinal adjustments to new environment and negligible career expectations. In contrast, good social skills were proved to benefit graduates with disabilities in terms of increased employability, job retention and job satisfaction (Murray \& Doren, 2013; Ofoegbu \& Azarmsa, 2010; Schafft, 2014). Such findings suggest that students with disabilities require more and better training in job-related social skills before entering the workplace. In this article, we focus on the teaching of job-related social skills provided to vocational high school students with intellectual disabilities enrolled in special or general education programs. We term these students "special education students" and graduates with disabilities from such programs "special education graduates”.

Extant research has well documented the job-related social skills that employers and teachers expect special education graduates to obtain (Chang \& Chen, 2004; Foss \& Peterson, 1981; Hsu, 2001; Moriarity, Walls, \& McLaughlin, 1988; Wu \& You, 2008) and debated the teaching strategies that aim to achieve the desirable job-related social skills (Feng, 1999; Huang, 2008; Huang \& Cuvo, 1997; Lin \& Feng, 2010; Whang, Fawcett \& Mathews, 1984; $\mathrm{Wu}, 2003)$. However, less is known about the quantity and quality of the provision of jobrelated social skills to students with disabilities in vocational schools, which has the potential to influence the employability of these students. Our study reported in this paper aims to make a contribution in this regard. Specifically, the study looks at the quantity and quality of teaching of job-related social skills provided to special education graduates in Taiwan; and the effects of teachers' backgrounds on their teaching practices. Nevertheless, the required job-related social skills, particularly those for special education graduates, warrant more discussion. 


\section{Job-Related Social Skills}

The concept of job-related social skills is complex and multidimensional. Previous studies have used a variety of similar terms to investigate this concept, including social skills in employment settings (Chadsey-Rusch, 1992), social skills in job-related settings (Huang \& Cuvo, 1997) and job-related social skills (Bullis \& Davis, 1996; Elksnin \& Sabornie, 1994). Chadsey-Rusch (1992) was the first scholar to structurally integrate these concepts and develop a more concrete construct of job-related social skills (Black \& Langone, 1997; Emecen, 2011; Feng, 1999; Morgan, Leatzow, Clark \& Siller, 2014; Neubert \& Moon, 2006). He conceptualised job-related social skills in terms of five components and contextualised these components within employment settings. The first component of job-related social skills refers to rule-governed learned behaviours that elicit positive or neutral responses to social interactions. The second component emphasises that job-related social skills can be learned and acquired so workers who have inadequate social skills can be taught. The third component considers these skills to be instrumental and goal-directed behaviours, indicating that job-related social skills are used for affecting current or future interactions. However, the skills are not fixed, which leads to the fourth component: job-related social skills are situation specific. In other words, these skills vary based on the environments, the people in the setting, and the social occasions in which the interactions are occuring. Finally, job-related social skills involve not only observable but also non-observable behaviours. The non-observable behaviours are used to decode social contexts or to make decisions about when to exhibit proper responses. In summary, job-related social skills can be defined as goal-oriented, rule-governed learned behaviours that are situation specific and vary according to social context; they involve both observable and non-observable cognitive and affective elements that assist in eliciting positive or neutral responses and avoiding negative responses from others.

Given the complexity of job-related social skills, it is hard to incorporate all five components in one study and to operationalise these skills into measurable items in a 
methodologically sound way. Despite this challenge, we drew insight from previous empirical studies and made an attempt to gauge the aforementioned components of jobrelated social skills. We tentatively proposed a two-dimension model of job-related social skills. First, we clustered social skills that affect employment indirectly but are indispensible to daily life, and named this cluster "basic job-related social skills". These skills include proper hygiene (Calkins \& Walker, 1990; Salzberg, Lignugaris/Kraft, \& McCuller, 1988; Walls \& Werner, 1977; Wehmen, 1976; Chang \& Chen, 2004), adaptive behaviour (Wehmen, 1976; Fornes, Rocco \& Rosenberg, 2008; Salzberg et al., 1988), punctuality (Calkins \& Walker, 1990; Walls \& Werner, 1977; Siegel et al., 1989; Wehmen, 1976; Salzberg et al., 1988) and verbal social skills (Wehmen, 1976; Calkins \& Walker, 1990; Chang \& Chen, 2004; Krajewski, Wiencek, Brady, Trapp \& Rice, 2010; Salzberg et al., 1988). Specifically, proper hygiene means cleanliness of an individual person, use of personal hygiene products, and appropriate dressing. Adaptive behaviour indicates the use of proper manners for dining and speaking. Punctuality refers to the completion of relevant tasks on time and the notification of superiors in advance when lateness might be expcted. Finally, appropriate verbal social skills are evidenced by the use of terms and responses in a culturally appropriate way, as well as the demonstration of body postures congruent with active and respectful listening.

The other dimension of job-related social skills, directly required by workplaces, we term "advanced job-related social skills". These skills are comprised of threecomponents: job responsibility (Wehmen, 1976; Bullis \& Foss, 1986; Chang \& Chen, 2004; Fornes, Rocco \& Rosenberg, 2008; Montaque, 1988; Salzberg et al, 1988;), cooperation (Wehmen, 1976; Chang \& Chen, 2004), and emotion management (Calkins \& Walker, 1990; Chang \& Chen, 2004; Walls \& Werner, 1977; Bullis \& Foss, 1986; Montaque, 1988; Salzberg et al., 1988; Bullis et al., 1993; ). Job responsibility refers to finishing tasks in a volitional manner, being 
positive at work, accepting instructions and working independently. Cooperation indicates the ability to work in teams and groups. The final component of advanced job-related social skills, emotion management, focuses on accepting criticism and handling teasing and provocation appropriately.

Both dimensions of job-related social skills are not easy to teach, especially to students with intellectual disabilities (Su, Wang \& Ko, 2012). Such individuals may experience difficulties in concentrating on learning and processing information (Chen, 1992), which makes them more vulnerable in the workplace. In educational contexts, very few teachers emphasise the importance of job-related social skills because job-related issues are considered to be the purview of social welfare and labor departments (Lin, 2002). Having said that, exceptions can be found in Taiwanese vocational high schools, which have engaged with the challenging of teaching job-related social skills to students with disabilities over the past two decades. It is the particular Taiwanese context that is our current focus.

\section{Background}

In Taiwan, vocational high schools are required to offer special education classes to help students with mild intellectual disabilities obtain knowledge about the workplace and increase their professional skills at work and social skills in life (Ministry of Education, 2000). The special education needs of these students cannot be met in regular classes and therefore are taught in special education classes. These classes are arranged in general/regular schools, but separated from mainstream classrooms. The curriculum can be divided into three parts: general subjects for functional math and life education, vocational subjects for professional skills (e.g. baking, catering, cleaning, and gardening), and practicum in preparation for the workplace. Furthermore, special education classes in Taiwanese vocational high schools are committed to the continual enhancement of job-related social skills of special education students. To this end, teachers in these schools are considerably involved in the development of various training materials and the 
implementation of approaches, such as simulated workplace settings (Whang et al., 1984), social integration (Huang \& Cuvo, 1997), cognitive straties (e.g. reinforcement, demonstration) (Feng, 1999), video demonstrations in teaching ( $\mathrm{Wu}, 2003)$, five-step self-teaching that includes cognitive modelling, overt external guidance, overt self-guidance, a gradual decrease in the use of overt self-guidance, and covert self-instruction (Huang, 2008), as well as self-management assessment like self-observation, self-recording (e.g. keeping a log book), self-assessment and self-reinforcement (Lin \& Feng, 2010). Throughout the system of Taiwanese vocational high schools, the connection between education and employment is emphasised. Thus, Taiwan provides a unique place to study the job preparation of special education students and special education graduates.

Special education teachers are widely recognised to play a leading role in teaching individuals with disabilities (Wang \& Mu, 2014). In this respect, special education teachers have the potential to enhance the employability of students with disabilities when these teachers engage in facilitiating the provision of job-related social skills for these students. Interestingly, empirical studies seem to suggest that the aforementioned pedagogical methods developed in Taiwanese vocational high schools are insufficient for the development of jobrelated social skills in special education students. For example, Chen and Wang (2007) found that special education students in vocational high schools had an unsatisfactory level of job readiness and job attitude. Chen and Lin (2000) tracked 97 special education graduates who left their jobs and they exhibited low levels of appropriate ethics and intensions to work, such disputations were responsible for this degree of attrition recorded. In addition, there is a dearth of knowledge about how teachers' backgrounds such as teaching experiences and qualifications influence the cultivation of effective job-related social skills which potentially contribute to the employability of special education graduates. To clarify, Taiwanese teachers with different qualifications receive different teacher training. For teachers with a general 
qualification, their training focuses more on their teaching discipline, for example, English or mathematics. In contrast, teachers with a special education qualification receive more training on how to teach students with special needs. As such, teachers with different qualifications may have epistemological differences in providing job-related social skills to special education students.

Given the important role of job-related social skills in the employability of special education students, this study attempts to investigate the effectiveness of teaching job-related social skills in Taiwanese vocational high schools. To this end, we scrutinise the pedagogical practices of teachers in selected vocational high schools in Taiwan with a particular focus on their teaching of job-related social skills to special education students.

\section{Methods}

\section{Participants}

In Taiwan, schools with more classes usually get more resources (Zhang \& Sheu, 2010; Zhang, Wang, \& Sheu, 2013) which could potentially promote better outcomes from their employment training for special education students. Therefore, in order to enhance the representativeness of the sample, we used stratified random sampling based on school size, taking account of the number of classes in schools. In this study, we looked at all 38 vocational high schools in Northern Taiwan. The population in the study is composed of all special education teachers at these schools. These 38 schools are comprised of 27 small-sized schools, seven medium-sized schools and four large-sized schools.

In the pilot phase, we firstly randomly selected one-third of the schools from each of the three different sized school strata. We then invited all special education teachers from each sampled school to voluntarily participate in our pilot study. In this vein, the pilot study ended up with 162 participants, including 113 participants in nine small-sized schools 
(response rate: $95.0 \%$ ), 31 participants in two medium-sized schools (response rate: $73.8 \%$ ), and 18 participants in one large-sized school (response rate: 100\%).

The remaining two-thirds of the 38 schools were used for the main study. Through the same stratified sampling approach, the main study enlisted 268 participants, including 163 participants in 18 small-sized schools (response rate: 88.9\%), 48 participants in five mediumsized schools (response rate: $77.1 \%$ ), and 57 participants in three large-sized schools (response rate: 84.2\%). These participants were then asked to conduct our formal questionnaires. From the above sampled schools, 268 questionnaires were distributed with a total of 203 questionnaires being collected after removing the invalid ones. The majority of participants were female (65.5 \%). Other characteristics of participants are presented in Table 1.

\section{[t] Insert Table 1 near here/[t]}

\section{Instrument}

Based on previous studies, a survey was developed to investigate the frequency of teaching jobrelated social skills. As noted earlier, these skills could be classified into basic job-related social skills and advanced job-related social skills. The initial pilot survey comprised 50 items in total, including nine negatively worded items designed to ensure valid responses. The pilot survey was tested by item analysis, construct validity and internal consistency analysis using the pilot sample. The internal consistency analysis was presented with Cronbach's $\alpha$ values. All $\alpha$ values fell within the range between .7 and .9, implying that the survey had good internal consistency (Kline, 2000). Six items were deleted because of their contribution to a low Cronbach's $\alpha$ value and their association with low factor loadings. Exploratory Factor Analysis (EFA) and Confirmatory Factor Analysis (CFA) were further used to test the validity of our instrument. All factor loadings of the 44 questions ranged between .72 and .85 , and the extraction sum of squared loadings were between $33.98 \%$ and $70.88 \%$ (see Table 2), indicating a fine validity of the measurement. 
Following the revisions, the total number of items in the formal survey was reduced to 44, including eight negatively worded items. This formal survey included two dimensions, namely basic job-related social skills and advanced job-related social skills. The former dimension contained four sub-dimensions: proper attire and hygiene (seven items), proper behaviour (six items), punctuality and attendance (seven items), and verbal social skills (six items). The latter dimension consisted of three sub-dimensions, namely job responsibility (six items), cooperation (four items), and emotion management (eight items).

\section{[t] Insert Table 2 near here/[t]}

\section{Data Analysis}

The survey used a four-point Likert-type scale with the categories of 'always', 'often', 'sometimes' and 'seldom'. Descriptive statistics were used to report on the percentages, frequencies, means $(M)$ and standard deviations $(S D)$ of the responses. A comparative analysis was conducted in two ways. First of all, we compared the strength of the sub-dimensions within each dimension of job-related social skills. Second of all, an F-test was used to analyse the mean difference in each of the two dimensions of job-related social skills across seven categorical variables: gender, qualifications, teaching experience in special education classes, practicum, general subjects, and vocational subjects as well as experience as homeroom teachers. Once overall significant differences were found; a Scheffé test was used for post-hoc comparisons. In addition to considering the significance level, we also reported the effect size $r$ to demonstrate the magnitude of the mean difference (Cohen, 1992; Field, 2009).

\section{Results and Discussion}

\section{The Current Status of Teaching Job-related Social Skills}

As shown in Table 3, overall there are significant differences amongst the sub-dimensions of jobrelated social skills $(M=3.56, S D=.44, p<.001, r=.25)$. When the two dimensions of jobrelated social skills were compared, teachers tended to cultivate basic job-related social skills 
more often than advanced job-related social skills (mean difference $=.11, S D=.25, p<.001, r$ $=.40)$. Within the dimension of basic job-related social skills, significant differences were found $(F=10.54, p<.001, r=.22)$ with proper attire and hygiene $(M=3.57, S D=.38)$ as well as punctuality and attendance $(M=3.55, S D=.30)$ cultivated less frequently than proper behaviour $(M=3.68, S D=.35)$; and with punctuality and attendance cultivated less frequently than verbal social skills $(M=3.62, S D=.40)$. Within the dimension of advanced job-related social skills, significant differences were also found ( $F=64.48, p<.001, r=.57$ ). Teachers tended to cultivate cooperation $(M=3.36, S D=.56)$ and emotion management $(M=3.42, S D=.44)$ less frequently than job responsibility $(M=3.70, S D=.41)$. The above findings were consistent with an early study by $\mathrm{Wu}$ and Chen (2007), that found that cooperation was less frequently taught. Such findings indicate that the cultivation of collaboration skills seems to be overlooked in teachers' pedagogical practices.

\section{[t] Insert Table 3 near here/[t]}

Notably, most teachers surveyed seemed to emphasise the teaching of job responsibility $(M=3.70, S D=.41)$, with up to $70.0 \%$ of the participants reporting that they always cultivated job responsibility. These findings are also consistent with previous studies (see Chang \& Chen, 2004; Foss \& Peterson, 1981; Hsu, 2001). In the current study, job responsibility was defined as finishing designated duties and tasks, performing positively and diligently, accepting advice and being able to work independently. Compared to other advanced skills, such as cooperation and emotion management, job responsibility has more feasibility to educate and cultivate. In other words, it appears that it is more feasible for teachers to cultivate job responsibility through discussions irrespective of settings. Thus, it may be easier to cultivate job responsibility in the classroom. 


\section{Teaching Job-related Social Skills and Teachers' Backgrounds}

Tables 4 and 5 summarise different teaching strategies in relation to the personal backgrounds of the teachers surveyed. As shown in Table 4, both male and female teachers scored higher than 3.5 in the overall job-related social skills and some sub-dimensions of job-related social skills, indicating that they had a particular focus on teaching proper attire and hygiene, proper behaviour, punctuality and attendance, verbal social skills and job responsibility in their classes. However, no significant gender difference was found in the cultivation frequency of different job-related social skills.

\section{[t] Insert Table 4 near here/[t]}

In relation to teachers' qualifications, as stated in Table 5, it was found that teachers with both general and special education qualifications taught job-related social skills significantly more frequently than teachers with either one of the qualifications. Specifically, teachers with only general education qualification scored significantly lower than those with both general and special education qualifications in the whole scale of job-related social skills (mean difference $=-.14, p<.05, r=.21$ ) and the advanced job-related social skills (mean difference $=-.19, p<.05, r=.23$ ). Among the sub-dimensions, teachers with both general and special education qualifications scored significantly higher than those with only general education qualification in punctuality and attendance (mean difference $=.19, p<.05, r=.25$ ), cooperation (mean difference $=.26, p<.05, r=.21$ ) and emotion management (mean difference $=.22, p<.05, r=.24)$. However, no significant difference was found in the overall scale and each dimension between teachers with only a general education qualification and those with only a special education qualification. These findings imply holding either one qualification may not be enough to prepare for the effective teaching of job-related social skills.

\section{[t] Insert Table 5 near here/[t]}




\section{Teaching Job-related Social Skills and Teaching Experience}

As set out in Tables 6 to 10, teachers with less experience in teaching or being homeroom teachers or those with no experience in teaching vocational, general or practicum subjects were associated with lower scores in both the full scale of job-related social skills and the two dimensions of job-related social skills in comparison with teachers with more experience in the aforementioned aspects. Specifically, less experienced teachers reportedly taught proper attire, hygiene, punctuality and attendance skills less frequently than experienced teachers (their effect size $r$ and significance level were all reported in the following tables).

\section{[t] Insert Table 6 near here/[t]}

\section{[t] Insert Table 7 near here/[t]}

\section{[t] Insert Table 8 near here/[t]}

\section{[t] Insert Table 9 near here/[t]}

\section{[t] Insert Table 10 near here/[t]}

Table 6 further shows teachers with over seven years of teaching experience scored significantly (at the .05 level) higher than their counterparts with under one year teaching experience in full scale (mean difference $=.21, p<.01, r=.17$ ), basic job-related social skills (mean difference $=.20, p<.01, r=.19$ ), advanced job-related social skills (mean difference $=.21, p<.05, r=.13$ ), proper attire and hygiene (mean difference $=.24, p<.01, r=.10$ ), punctuality and attendance (mean difference $=.34, p<.001, r=.31$ ), and job responsibility (mean difference $=.20, p<.05, r=.13$ ).

Table 9 shows teachers with more experience in teaching vocational subjects were found to instruct all job-related social skills except verbal social skills more frequently (significance at the .05 level) than their counterparts with less experience. Furthermore, our results showed that teachers with more teaching experience in vocational subjects had higher 
scores than the less experienced teachers on almost every sub-dimension of job-related social skills.

According to these findings, it can be inferred that veteran teachers are more likely to be aware of the importance of overall job-related social skills and reinforce them through their pedagogical practices. These results also indicate that experienced teachers focus more on job-related social skills than novice teachers. Interestingly, results from our study stood in contrast to those from Liu (2002), who found that young teachers placed significantly more emphasis on job-related social skills than experienced ones. Hence, this difference suggests that further studies are required to explore this discrepancy, i.e., whether teachers with different years of teaching experiences perform differently in their pedagogical practices when providing job-related social skills to special education students.

Additionally, teaching experience seemed to have a particular impact on the frequency of teaching proper attire, hygiene, punctuality and attendance. Calkins and Walker (1990) emphasised the importance of punctuality and dressing neatly. The current study aligns with extant work, showing that teachers with less experience cultivate proper attire, hygiene, punctuality and attendance significantly less than more experienced teachers. This suggests that experienced teachers have a better understanding of what employers and the real workplace require, and thus, have linked this knowledge to their teaching practice.

\section{Conclusion}

This study investigated teachers' pedagogical practices when teaching job-related social skills to special education students in vocational high schools in Northern Taiwan, where improving the employability of special education graduates has been a focus of service for decades. In the current study, a statistically and contextually reliable and valid multi-dimensional instrument for job-related social skills has been developed and validated. The results demonstrated that teachers taught students basic job-related social skills significantly more frequently than advanced job- 
related social skills. Specifically, the teaching of some advanced job-related social skills, such as cooperation and emotion management, was particularly inadequate. No gender difference was found in the cultivation frequency of job-related social skills, while teacher qualification and teaching experiences were found to be significant factors that influenced the teaching of jobrelated social skills.

The findings from the current study, though not surprising, provide insightful implications for special education practices. Compared to basic job-related social skills, advanced job-related social skills were inadequately taught. This is somewhat disappointing and problematic, because advanced job-related social skills are desperately required by the workplace. Here we are not underestimating the benefits of those basic job-related social skills. Instead, we are arguing that the inadequate provision of advanced job-related social skills would place special education graduates at double risk: They are biographically associated with disabilities and they are socially associated with low employability. What further worries us is that very few teachers reportedly engaged with the teaching of the skills for cooperation. Teachers in a special education classroom commonly focussed more on the needs of individuals, but neglected the importance of teamwork, at least to a certain extent. Special education students, despite their special educational needs, cannot be treated as static and passive receivers of knowledge. Instead, they should be taught as active participants, where their engagement in the learning process is crucial. Moreover, they require more practice than their peers without disabilities. In this respect, teachers are encouraged to develop and execute more team activities in class so that the classroom can be shaped into a more engaging and enabling social space for special education students.

This study also revealed that less experienced teachers cultivated job-related social skills at a lower frequency. This raises a concern about special education teacher training programs. The pre-service teacher training programmes should further highlight the 
importance of the provision of job-related social skills for special education students. This will convey to teachers that the recognition of that such pedagogical provision of these skills is not supplementary but essential. The in-service teacher training programmes might create mentoring modules where experienced teachers can pass on the "know-how" capacity to novice teachers.

Finally, our results showed that teachers with more experience in teaching vocational subjects cultivated job-related social skills more often than teachers with less experience in this aspect. These vocational subjects are practice-driven and have real world relevance. Such subjects construct simulated workplaces for special education students. Thus, it is suggested that the curricula have more vocational subjects. In this way, teachers may perform their pedagogical practices to cultivate students' job-related social skills while teaching vocational subjects.

Given the limitations and scope of our research, we were only concerned how teachers’ personal attributes (e.g. teaching experiences) shaped their pedagogical practices in the cultivation of job-related social skills. Further research is required at a global level to examine this issue at a system level. Questions relating to how our system might become more supportive in nurturing the provision of job-related social skills for special education students deserve scholarly attention. Our research is situated in a Taiwanese context. Nevertheless, the employability of special education graduates is not aunique problem, but rather an issue more broadly. We hope lessons learnt and knowledge built through our Taiwanese study can inform special education teachers’ pedagogical practices elsewhere.

\section{Disclosure Statement}

No potential conflict of interest was reported by the authors. 
16 Y-A Chu and L-C Zhang

\section{Funding}

There was no research funding for this study, and no restrictions have been imposed on free access to, or publication of, the research data.

\section{Acknowledgements}

This paper is completed with the generous help and kind support of Dr. Bey-Lih Chang and Dr.

Jia-Jia Syu. We also thank anonymous referees and the editor Dr. Guanglun Michael Mu for comments that greatly improved the manuscript. Any remaining errors, of course, are solely our responsibility. 
Table 1. Participant demographic characteristics $(\mathrm{N}=203)$.

\begin{tabular}{|c|c|c|}
\hline Personal Variables & $\mathrm{n}$ & $\%$ \\
\hline \multicolumn{3}{|l|}{ Gender } \\
\hline Male & 70 & 34.5 \\
\hline Female & 133 & 65.5 \\
\hline \multicolumn{3}{|l|}{ Teacher qualification } \\
\hline General & 84 & 41.4 \\
\hline Special & 66 & 32.5 \\
\hline Both & 53 & 26.1 \\
\hline \multicolumn{3}{|c|}{ Teaching Experience Variables } \\
\hline \multicolumn{3}{|c|}{ Years of teaching in special class in vocational high school } \\
\hline Under 1 year & 40 & 19.7 \\
\hline $1-7$ years & 88 & 43.3 \\
\hline Over 7 years & 75 & 36.9 \\
\hline \multicolumn{3}{|c|}{ Years as homeroom teacher in special class in vocational high school } \\
\hline None & 115 & 56.7 \\
\hline $1-5$ years & 62 & 30.5 \\
\hline Over 5 years & 25 & 12.3 \\
\hline Missing data & 1 & 0.5 \\
\hline \multicolumn{3}{|c|}{ Years of teaching general subjects } \\
\hline Under 1 year & 72 & $\begin{array}{l}35.5 \\
38.4\end{array}$ \\
\hline 1-7 year & 78 & 38.4 \\
\hline Over 7 years & 39 & $\begin{array}{r}19.2 \\
6.0\end{array}$ \\
\hline Missing data & 14 & 6.9 \\
\hline \multicolumn{3}{|c|}{ Years of teaching vocational subjects } \\
\hline Under 1 year & 78 & 38.4 \\
\hline $1-7$ year & 79 & 38.9 \\
\hline Over 7 years & 36 & 17.7 \\
\hline Missing data & 10 & 4.9 \\
\hline \multicolumn{3}{|c|}{ Years of teaching practicum } \\
\hline Under 1 year & 102 & 50.2 \\
\hline 1-7 year & 78 & 38.4 \\
\hline Over 7 years & 17 & 8.4 \\
\hline Missing data & 6 & 3.0 \\
\hline
\end{tabular}


Table 2. The reliability and validity of the scale of job-related social skills (pilot study sample, $\mathrm{N}=162)$.

\begin{tabular}{lll}
\hline Dimensions & Cronbach's $\alpha$ value & $\begin{array}{l}\text { Extraction sum of } \\
\text { squared loading (\%) }\end{array}$ \\
\hline Full scale & .96 & 34.16 \\
\hline Basic job-related social skills & .93 & 33.98 \\
Proper attire and hygiene & .81 & 46.14 \\
Proper behaviour & .79 & 47.32 \\
Punctuality and attendance & .81 & 40.78 \\
Verbal social skills & .86 & 57.63 \\
\hline Advanced job-related social skills & .92 & 44.55 \\
Job responsibility & .88 & 67.51 \\
Cooperation & .86 & 70.88 \\
Emotion management & .88 & 53.39 \\
\hline
\end{tabular}


Table 3. The analysis of the current status of teachers' cultivation of job-related social skills $(\mathrm{N}=203)$.

\begin{tabular}{|c|c|c|c|c|c|c|c|c|}
\hline \multirow[b]{2}{*}{ Dimensions } & \multicolumn{6}{|c|}{ Response scale $^{\mathrm{a}}$} & \multirow{2}{*}{$-F$} & \multirow{2}{*}{ Post-hoc ${ }^{b}$} \\
\hline & 1 & 2 & 3 & 4 & $M$ & $S D$ & & \\
\hline Full scale & $\begin{array}{l}0 \\
(0 \%)\end{array}$ & $\begin{array}{l}0 \\
(0 \%)\end{array}$ & $\begin{array}{l}80 \\
(39.4 \%)\end{array}$ & $\begin{array}{l}123 \\
(60.6 \%)\end{array}$ & 3.56 & .44 & $14.36 * * *$ & $\begin{array}{l}1<7 \\
2<3,7\end{array}$ \\
\hline Basic job-related social skills & $\begin{array}{l}0 \\
(0 \%)\end{array}$ & $\begin{array}{l}0 \\
(0 \%)\end{array}$ & $\begin{array}{l}68 \\
(33.5 \%)\end{array}$ & $\begin{array}{l}135 \\
(66.5 \%)\end{array}$ & 3.61 & .38 & & $\begin{array}{l}4<3,7 \\
6<1,3\end{array}$ \\
\hline Proper attire and hygiene & $\begin{array}{l}0 \\
(0 \%)\end{array}$ & $\begin{array}{l}1 \\
(0.5 \%)\end{array}$ & $\begin{array}{l}75 \\
(37.0 \%)\end{array}$ & $\begin{array}{l}127 \\
(62.6 \%)\end{array}$ & 3.57 & .38 & & $\begin{array}{l}8<1,2,3,4,5,6,7,9 \\
9<1,2,3,4,5,6,7\end{array}$ \\
\hline Proper behaviour & $\begin{array}{l}0 \\
(0 \%)\end{array}$ & $\begin{array}{l}1 \\
(0.5 \%)\end{array}$ & $\begin{array}{l}39 \\
(19.2 \%)\end{array}$ & $\begin{array}{l}163 \\
(80.3 \%)\end{array}$ & 3.68 & .35 & & $r=.25$ \\
\hline Punctuality and attendance & $\begin{array}{l}0 \\
(0 \%)\end{array}$ & $\begin{array}{l}2 \\
(1.0 \%)\end{array}$ & $\begin{array}{l}76 \\
(37.4 \%)\end{array}$ & $\begin{array}{l}125 \\
(61.6 \%)\end{array}$ & 3.55 & .39 & & \\
\hline Verbal social skills & $\begin{array}{l}0 \\
(0 \%)\end{array}$ & $\begin{array}{l}0 \\
(0 \%)\end{array}$ & $\begin{array}{l}65 \\
(32.0 \%)\end{array}$ & $\begin{array}{l}138 \\
(68.0 \%)\end{array}$ & 3.62 & .40 & & \\
\hline Advanced job-related social skills & $\begin{array}{l}0 \\
(0 \%)\end{array}$ & $\begin{array}{l}1 \\
(0.5 \%)\end{array}$ & $\begin{array}{l}94 \\
(46.3 \%)\end{array}$ & $\begin{array}{l}108 \\
(53.2 \%)\end{array}$ & 3.50 & .50 & & \\
\hline Job responsibility & $\begin{array}{l}0 \\
(0 \%)\end{array}$ & $\begin{array}{l}1 \\
(0.5 \%)\end{array}$ & $\begin{array}{l}60 \\
(30.5 \%)\end{array}$ & $\begin{array}{l}142 \\
(70.0 \%)\end{array}$ & 3.70 & .41 & & \\
\hline Cooperation & $\begin{array}{l}0 \\
(0 \%)\end{array}$ & $\begin{array}{l}9 \\
(4.4 \%)\end{array}$ & $\begin{array}{l}99 \\
(48.8 \%)\end{array}$ & $\begin{array}{l}95 \\
(46.8 \%)\end{array}$ & 3.36 & .56 & & \\
\hline Emotion management & $\begin{array}{l}0 \\
(0 \%)\end{array}$ & $\begin{array}{l}1 \\
(0.5 \%)\end{array}$ & $\begin{array}{l}97 \\
(47.8 \%)\end{array}$ & $\begin{array}{l}105 \\
(51.7 \%)\end{array}$ & 3.42 & .44 & & \\
\hline
\end{tabular}

Note: ${ }^{a}$ Four-point Likert-type scale (from 1 = Seldom to 4 = Always). ${ }^{b} 1=$ Basic job-related social skills, $2=$ Proper attire and hygiene, $3=$ Proper behaviour, 4 = Punctuality and attendance, 5 = Verbal social skills, $6=$ Advanced job-related social skills, $7=$ Job responsibility, $8=$ Cooperation, $9=$ Emotion management, and $r$ denotes the measure of effect size.

$* * * p<.001$. 
Table 4. Teachers' cultivation of job-related social skills by gender $(\mathrm{N}=203)$.

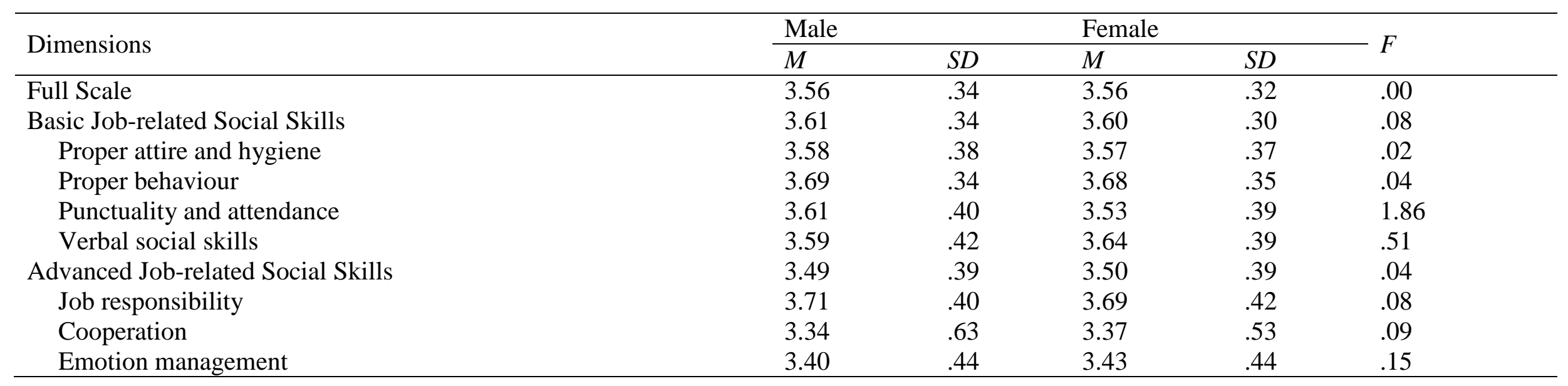


Table 5. Cultivating job-related social skills by teachers with different teacher qualifications $(\mathrm{N}=203)$.

\begin{tabular}{|c|c|c|c|c|c|c|c|c|}
\hline Dimensions & \multicolumn{2}{|c|}{$\begin{array}{l}\text { Teachers with } \\
\text { only general } \\
\text { qualification }\end{array}$} & \multicolumn{2}{|c|}{$\begin{array}{l}\text { Teachers with } \\
\text { only special } \\
\text { education } \\
\text { qualification }\end{array}$} & \multicolumn{2}{|c|}{$\begin{array}{l}\text { Teachers with } \\
\text { above both } \\
\text { qualifications }\end{array}$} & $F$ & Post-hoc $^{\mathrm{a}}$ \\
\hline Full Scale & 3.51 & .339 & 3.55 & .316 & 3.65 & .304 & $3.15^{*}$ & $1<3 ; r=.21$ \\
\hline Basic Job-related Social Skills & 3.53 & .397 & 3.57 & .363 & 3.64 & .362 & 2.09 & \\
\hline Proper attire and hygiene & 3.57 & .326 & 3.58 & .303 & 3.68 & .303 & 1.31 & \\
\hline Verbal social skills & 3.57 & .434 & 3.62 & .346 & 3.70 & .406 & 1.58 & \\
\hline Advanced Job-related Social Skills & 3.42 & .408 & 3.51 & .376 & 3.61 & .352 & $3.96 *$ & $1<3 ; r=.23$ \\
\hline Job responsibility & 3.65 & .641 & 3.71 & .498 & 3.76 & .470 & 1.20 & \\
\hline Cooperation & 3.24 & .641 & 3.39 & .498 & 3.50 & .470 & $3.63 *$ & $1<3 ; r=.21$ \\
\hline Emotion management & 3.33 & .448 & 3.42 & .460 & 3.55 & .386 & $3.84 *$ & $1<3 ; r=.24$ \\
\hline
\end{tabular}

Note: ${ }^{\text {a }} 1$ = Teachers with a general qualification, 2 = Teachers with a special education qualification, $3=$ Teachers with above both qualifications, and $r$ denotes the measure of effect size.

${ }^{*} p<.05$. 
Table 6. Cultivating job-related social skills by teachers with different years of teaching experience $(\mathrm{N}=203)$.

\begin{tabular}{|c|c|c|c|c|c|c|c|c|}
\hline \multirow{2}{*}{ Dimensions } & \multicolumn{2}{|c|}{ Under 1 year } & \multicolumn{2}{|c|}{ 1-7 years } & \multicolumn{2}{|c|}{ Over 7 years } & \multirow{2}{*}{$F$} & \multirow{2}{*}{ Post-hoc ${ }^{\mathrm{a}}$} \\
\hline & $M$ & $S D$ & $M$ & $S D$ & $M$ & $S D$ & & \\
\hline Basic Job-related Social Skills & 3.47 & .32 & 3.60 & .30 & 3.67 & .31 & $5.32 * *$ & $1<3 ; r=.19$ \\
\hline Proper behaviour & 3.62 & .35 & 3.68 & .35 & 3.71 & .33 & 0.79 & \\
\hline Punctuality and attendance & 3.32 & .43 & 3.57 & .37 & 3.66 & .35 & $10.79 * * *$ & $1<2,3 ; r=.31$ \\
\hline Verbal social skills & 3.53 & .41 & 3.65 & .39 & 3.64 & .41 & 1.33 & \\
\hline Advanced Job-related Social Skills & 3.38 & .43 & 3.48 & .39 & 3.59 & .35 & $4.13^{*}$ & $1<3 ; r=.13$ \\
\hline Cooperation & 3.23 & .59 & 3.33 & .59 & 3.47 & .50 & 2.79 & \\
\hline Emotion management & 3.31 & .44 & 3.39 & .46 & 3.51 & .42 & 2.90 & \\
\hline
\end{tabular}

Note: ${ }^{\mathrm{a}} 1$ = under 1 year, 2 = 1-7 years, 3 = over 7 years, and $r$ denotes the measure of effect size.

${ }^{*} p<.05 ; * * p<.01 ; * * * p<.001$. 
Table 7. Cultivating job-related social skills by teachers with different practicum teaching experience $(\mathrm{N}=203)$.

\begin{tabular}{|c|c|c|c|c|c|c|c|c|}
\hline \multirow{2}{*}{ Dimensions } & \multicolumn{2}{|c|}{ Under 1 year } & \multicolumn{2}{|c|}{$1-7$ years } & \multicolumn{2}{|c|}{ Over 7 years } & \multirow{2}{*}{$F$} & \multirow{2}{*}{ Post-hoc ${ }^{\mathrm{a}}$} \\
\hline & $M$ & $S D$ & $M$ & $S D$ & $M$ & $S D$ & & \\
\hline Basic Job-related Social Skills & 3.52 & .32 & 3.69 & .28 & 3.68 & .32 & $7.62 * *$ & $1<2 ; r=.20$ \\
\hline Proper behaviour & 3.64 & .36 & 3.72 & .33 & 3.77 & .29 & 1.73 & \\
\hline Punctuality and attendance & 3.44 & .40 & 3.69 & .33 & 3.63 & .38 & $10.50 * * *$ & $1<2 ; r=.23$ \\
\hline Verbal social skills & 3.56 & .41 & 3.70 & .36 & 3.65 & .47 & 2.71 & \\
\hline Advanced Job-related Social Skills & 3.41 & .41 & 3.59 & .35 & 3.59 & .34 & $5.75^{* *}$ & $1<2 ; r=.15$ \\
\hline Cooperation & 3.23 & .61 & 3.48 & .48 & 3.49 & .50 & $4.96 * *$ & $1<2 ; r=.19$ \\
\hline Emotion management & 3.34 & .43 & 3.48 & .46 & 3.51 & .42 & 2.78 & \\
\hline
\end{tabular}

Note: ${ }^{\mathrm{a}} 1$ = under 1 year, 2 = 1-7 years, 3 = over 7 years, and $r$ denotes the measure of effect size.

${ }^{*} p<.05 ;{ }^{* *} p<.01 . ; * * p<.001$. 
Table 8. Cultivating job-related social skills by teachers with different general subjects teaching experience $(\mathrm{N}=203)$.

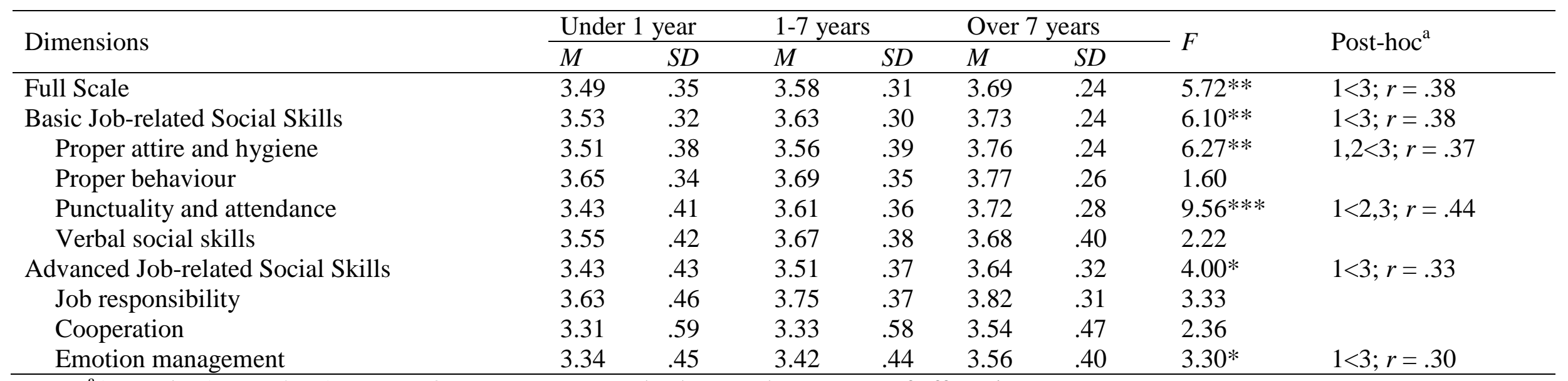

Note: ${ }^{\mathrm{a}} 1$ = under 1 year, $2=1-7$ years, $3=$ over 7 years, and $r$ denotes the measure of effect size.

${ }^{*} p<.05 ;{ }^{* *} p<.01 . ; * * p<.001$. 
Table 9. Cultivating job-related social skills by teachers with different vocational subjects teaching experience $(\mathrm{N}=203)$.

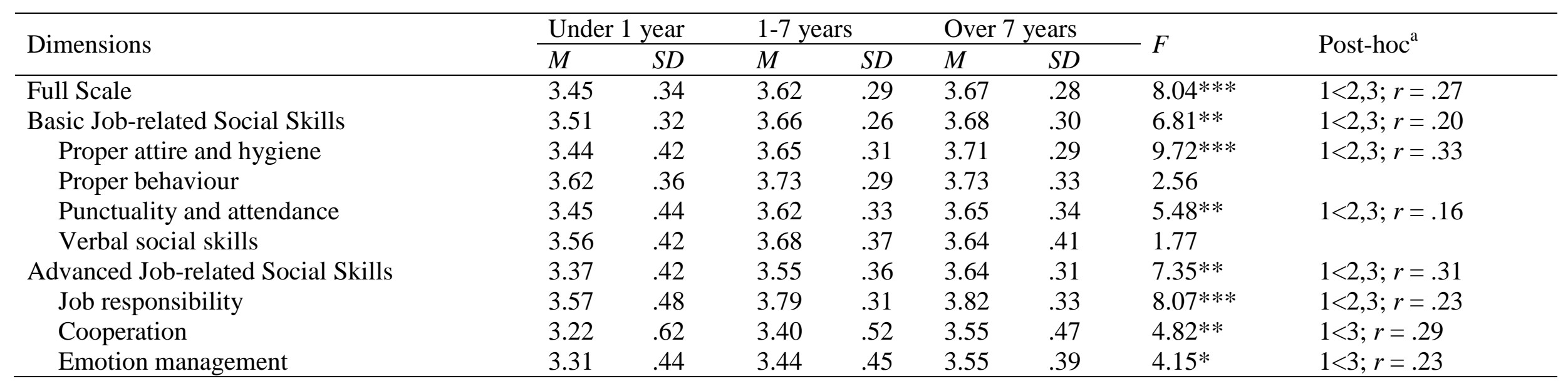

Note: ${ }^{\mathrm{a}} 1$ = under 1 year, $2=1-7$ years, 3 = over 7 years, and $r$ denotes the measure of effect size.

${ }^{*} p<.05 ; * * p<.01 . ; * * p<.001$. 
Table 10. Cultivating job-related social skills by teachers with different experience of being homeroom teachers $(\mathrm{N}=203)$.

\begin{tabular}{|c|c|c|c|c|c|c|c|c|}
\hline \multirow{2}{*}{ Dimensions } & \multicolumn{2}{|c|}{ Never } & \multicolumn{2}{|c|}{$1-5$ years } & \multicolumn{2}{|c|}{ Over 5 years } & \multirow{2}{*}{$F$} & \multirow{2}{*}{ Post-hoc ${ }^{\text {a }}$} \\
\hline & $M$ & $S D$ & $M$ & $S D$ & $M$ & $S D$ & & \\
\hline Basic Job-related Social Skills & 3.54 & .31 & 3.68 & .32 & 3.70 & .23 & $5.96 * *$ & $1<2 ; r=.22$ \\
\hline Proper behaviour & 3.65 & .35 & 3.75 & .35 & 3.67 & .30 & 1.78 & \\
\hline Punctuality and attendance & 3.47 & .41 & 3.63 & .36 & 3.72 & .28 & $6.36 * *$ & $1<2,3 ; r=.22$ \\
\hline Verbal social skills & 3.58 & .41 & 3.69 & .39 & 3.65 & .38 & 1.70 & \\
\hline Advanced Job-related Social Skills & 3.44 & .40 & 3.59 & .36 & 3.53 & .36 & $3.16^{*}$ & $1<2 ; r=.15$ \\
\hline Cooperation & 3.29 & .61 & 3.50 & .47 & 3.30 & .48 & 3.08 & \\
\hline Emotion management & 3.36 & .43 & 3.49 & .45 & 3.49 & .45 & 2.26 & \\
\hline
\end{tabular}

Note: ${ }^{\mathrm{a}} 1$ = Never, 2 = 1-5 years, 3 = over 5 years, and $r$ denotes the measure of effect size.

${ }^{*} p<.05 ; * * p<.01$. 


\section{Reference}

Black, R. S., \& Langone, J. (1997). Social awareness and transition to employment for adolescents with mental retardation. Remedial \& Special Education, 18(4), 214-222. doi: $10.1177 / 074193259701800403$

Bullis, M., \& Davis, C. (1996). Further examination of job-related social skills measures for adolescents and young adults with emotional and behavioral disorders. Behavioral Disorders, 21(2), 161-172.

Bullis, M., \& Foss, G. (1986). Guidelines for assessing the job-related social skills of mildly handicapped students. Career Development for Exceptional Individuals, 9, 89-97. doi: $10.1177 / 088572888600900204$

Calkins, C. F., \& Walker, H. M. (1990). Social competence for workers with developmental disabilities: A guide to enhancing employment outcomes in integrated settings. Baltimore. MD: Brookes.

Chadsey-Rusch, J. (1992). Toward defining and measuring social skills in employment setting. American Journal on Mental Retardation, 96(4), 405-418.

Chang, W. F., \& Chen, C. C. (2004). The development of the employability skills scale. Journal of Special Education, 20, 103-140.

Chen, C. C., \& Lin S. T. (2000). Develop intellectual disabilities vocational assessment tool. Taipei, Taiwan: Workforce Development Agency.

Chen, J. H. (1992). The Research of Mental Retardation. Taipei, Taiwan: Lucky Bookstore.

Chen, S. Y., \& Wang, C. H. (2007). Research in vocational students with intellectual disabilities in the job readiness. In C. F. Chang (Ed.), The resource and supports of special education-Annual Journal of Special Education (pp.237-256). Taipei, Taiwan: Special education association of the Republic of China. 
Cohen, J. (1992). A power primer. Psychological Bulletin, 112(1), 155-159. doi: 10.1037/0033-2909.112.1.155

Emecen, D. D. (2011). Comparison of direct instruction and problem solving approach in teaching social skills to children with mental retardation. Educational Sciences: Theory \& Practice, 11(3), 1414-1420.

Elksnin, L. K., \& Sabornie, E. J. (1994). Job-related social skills instruction of adolescents with mild mental retardation. The Journal for Vocational Special Needs Education, 17(1), 1-7.

Fasching, H. (2014). Vocational education and training and transitions into the labour market of people with intellectual disabilities. European Journal of Special Needs Education, 29(4), 505-520.

Feng, S. H. (1999). The use of cognitive strategies to teach social skills to work with intellectual disability. Special Education Quarterly, 72, 31-36.

Field, A. P. (2009). Discovering statistics using SPSS (3rd ed.). Los Angeles, CA: SAGE Publications.

Fornes, S., Rocco, T. S., \& Rosenberg, H. (2008). Improving outcomes for workers with mental retardation. Human Resource Development Quarterly, 19(4), 373-395. doi: 10.1002/hrdq.1246

Foss, G., \& Peterson, S. L. (1981). Social-interpersonal skills relevant to job tenure for mentally retarded adults. American Association on Mental Deficiency, 19(3), 103-106.

Hsu, M. S. (2001). A study of employers' and teachers' opinions about the job-related social skills for mentally retarded. (Unpublished master’s thesis). National Changhua Normal University, Changhua, Taiwan. 
Huang, M. H. (2008). The effects of self-instructional training on job-related social skills of special education class students at vocational senior high school. (Unpublished master's thesis). National Changhua University of Education, Changhua, Taiwan.

Huang, W., \& Cuvo, A. J. (1997). Social skills training for adults with mental retardation in job-related setting. Behavior Modification, 21(1), 3-44. doi: $10.1177 / 01454455970211001$

Kline, P. (2000). The handbook of psychological testing (2nd ed.). London: Routledge.

Krajewski, E. R., Wiencek, P., Brady, S. R., Trapp, E., \& Rice Jr. (2010). Teaching employable skills to special education youth: An empowerment approach. The International Journal of Interdisciplinary Social Sciences, 5(1), 167-176.

Lin, H. C. (2002). The practice and reflection of disabilities employment transition in America. Special Education Quarterly, 83, 1-12.

Lin, H. C., \& Feng, H. (2010). The effect of self-management on the job-related social skills assessment for an adult with Autism. Journal of Disability Research, 8(4), 256-274.

Liu, T. M. (2002). The views of teachers and employment counsellors for students with mild mental retardation job-related social skills and employment adaptation. (Unpublished master's thesis). National Changhua University of Education, Changhua, Taiwan.

Ministry of Education. (2000). The curriculum syllabus of vocational high school special education classes. Taipei, Taiwan: Special Education Unit.

Montaque, M. (1988). Job-related social skills training for adolescents with handicaps. Career Development for Exceptional Individual, 11(1), 26-41. doi: $10.1177 / 088572888801100105$

Morgan, L., Leatzow, A., Clark, S., \& Siller, M. (2014). Interview skills for adults with autism spectrum disorder: A pilot randomized controlled trial. Journal of Autism and Developmental Disorders, 44(9), 290-300. doi: 10.1007/s10803-014-2100-3 
Moriarity, J., Walls, R., \& McLaughlin, D. (1988). Employability of clients served in state vocational rehabilitation agencies: A national census. Rehabilitation Counselling Bulletin, 32(2), 108-121.

Murray, C., \& Doren, B. (2013). The effects of working at gaining employment skills on the social and vocational skills of adolescents with disabilities: A school-based intervention. Rehabilitation Counselling Bulletin, 56(2), 96-107. doi: 10.1177/0034355212452614

Ofoegbu, N., \& Azarmsa, R. (2010). Impact of the special education vocational education program (VEP) on student career success. International Journal of Special Education, 25(2), 34-46.

Neubert, D. A., \& Moon, M. S. (2006). Postsecondary settings and transition services for students with intellectual disabilities: Models and research. Focus on Exceptional Children, 39(4), 1-8.

Salzberg, C. L., Lignugaris/Kraft, B., \& McCuller, G. L. (1988). Reasons for job loss: A review of employment termination studies of mentally retarded workers. Research in Developmental Disabilities, 9(2), 153-170. doi: 10.1016/0891-4222(88)90049-2

Schafft, A. (2014). Employer guides: Improving job retention for people with mental health issues. Experiences from a Norwegian pilot project. Journal of Vocational Rehabilitation, 41(1), 23-27.

Siegel, S., Greener, K., Prieur, J., Robert, M., \& Gaylord-Ross, R. (1989). The community vocational training program: a transition program for youths with mild handicaps. Career Development for Exceptional Individuals, 12, 48-64. doi: $10.1177 / 088572888901200106$

Su, Y. C., Wang, H. Y., \& Ko, Y. C. (2012). The analysis of the effective in the implementation of social skills of students with. Journal of Special Education \& Assistive Technology, 8, 89-95. 
Walls, R. T., \& Werner, T. J. (1977). Vocational Behavior Checklist. Mental Retardation, 15(4), 30-35.

Wang, Y., \& Mu, G. M. (2014). Revisiting the trajectories of special teacher education in China through policy and practice. International Journal of Disability, Development and Education, 61(4), 346-361. doi 10.1080/1034912X.2014.955792

Wehman, P. H. (1976). Toward a social skills curriculum for developmentally disabled clients in vocational settings. Rehabilitation Literature, 36, 342-348.

Wehman, P., Fong, C., Ditchman, N., \& Hyun-Ju, K. (2014). Effect of supported employment on vocational rehabilitation outcomes of transition-age youth with intellectual and developmental disabilities: A case control study. Intellectual \& Developmental Disabilities, 52(4), 296-310. doi: 10.1352/1934-9556-52.4.296

Whang, P. L., Fawcett, S. B., \& Mathews, R. M. (1984). Teaching job-related social skills to learning disabled adolescents. Analysis and Intervention in Developmental Disabilities, 4(1), 29-38. doi: 10.1016/0270-4684(84)90016-8

Wu, C. H., \& Chen, C. C. (2007). An exploratory survey of the job requirements of employed graduates with intellectual disabilities in senior vocational high schools. Rehabilitation Counseling, 1, 17-46.

$\mathrm{Wu}, \mathrm{H}$. E. (2003). Research of students with intellectual disabilities in the workplace effectiveness of teaching social skills teaching video demonstration of moderate to severe. (Unpublished master’s thesis). National Changhua University of Education, Changhua, Taiwan.

Wu, L. R., \& You, S. P. (2008). Comprehensive functions of the division of vocational teachers of students with intellectual disabilities in professional skills of nonprofessional capacity needs of views. Training and Development, 3, 44-51. 
Zhang, L. -C., Wang, B. -J., \& Sheu, T-M. (2010). Evaluating the adequacy of meeting student performance standards in the Taipei city public elementary schools. Journal of Education and Psychology, 33(4), 109-136.

Zhang, L. -C., \& Sheu, T. -M. (2013). Effective investment strategies on mathematics performance in rural areas. Quality \& Quantity, 47(5), 2999-3017. doi 10.1007/s11135012-9752-X 